\title{
BLACK Ni-BASED GALVANIC COATINGS
}

\author{
Ekaterina SHCHERBINA, Aleksey ABRASHOV, Nelya GRIGORYAN, Tigran VAGRAMYAN, \\ Vladimir MEN'SHIKOV
}

\author{
MUCTR - D.Mendeleev University of Chemical Technology of Russia, Moscow, Russian Federation, \\ katerina.sherbin@mail.ru
}

https://doi.org/10.37904/metal.2019.901

\begin{abstract}
In recent years, black nickel-based functional coatings are increasingly being used as a worthy alternative to chromium coatings on steel, since such coatings provide not only an aesthetic appearance, but also effective corrosion protection.
\end{abstract}

The known technologies of applying black nickel coatings do not allow obtaining coatings with the required corrosion and wearing resistance. In addition, these technologies involve the mandatory pre-deposition of copper or nickel underlayer. The aim of the present work is the improvement of the technological process of applying black nickel coatings. Plates of cold-rolled steel were used as samples. A stepwise method of the cathode current density change for deposition of black nickel-containing coatings is proposed. Electrodeposition was carried out from a solution of the following composition, g/ I: $\mathrm{NiSO}_{4} \cdot 7 \mathrm{H}_{2} \mathrm{O}-100$; $\left(\mathrm{NH}_{4}\right)_{2} \mathrm{SO}_{4}-15 ; \mathrm{ZnSO}_{4} \cdot 7 \mathrm{H}_{2} \mathrm{O}-40 ; \mathrm{NH}_{4} \mathrm{CNS}-15 ; \mathrm{H}_{3} \mathrm{BO}_{3}-25$.

Keywords: Electrodeposition of metals, black nickel coatings, light-absorbing coatings, solar receiving devices, abrasion resistance, protective ability, $x$-ray fluorescence spectrometry

\section{INTRODUCTION}

Light and heat absorbing coatings are widely used in electro-optical systems, in instrument engineering to reduce the diffuse background light, and also in converters of solar energy into thermal energy for energyintensive devices. Most often, black chrome plating is applied to the absorbing surfaces of the solar cells, which gives the surface the required optical characteristics, corrosion and wear resistance [1,2]. However, the deposition of black chrome plating is quite difficult to implement technically. In addition, it is a power-consuming process with the use of highly toxic solutions.

In recent years, black nickel-based functional coatings are increasingly being applied as a worthy alternative to chromium-based coatings on steel, since such coatings provide not only an aesthetic appearance, but also effective protection against corrosion. Besides, black nickel coatings are used for protective and decorative finishes in various industries instead of black oxide coatings, due to their higher hardness and strength compared to oxide ones [3-6].

The applied processes of "black nickel plating" have such disadvantages as low rates of corrosion resistance of deposited coatings, their plasticity and poor adhesion to the base metal, especially when applied to steel. In addition, these technologies involve the mandatory pre-application of copper or nickel underlayer. The corrosion resistance of the coating is determined mainly by the corrosion resistance of the underlayer [7].

This study is devoted to the development of the process of obtaining black nickel-containing electroplating coatings.

\section{EXPERIMENTAL MATERIALS}

Plates of cold rolled steel $3 \times 4 \mathrm{~cm}$ were used as samples. Solutions were prepared from pure and analytical grades of chemicals and distilled water. To determine the quality of the coating, the angular Hull cell was used; the average cathode current density was $1 \mathrm{~A} / \mathrm{dm}^{2}$. 
The porosity of the resulting coatings was determined in accordance with GOST 9.302-88 (p. 4) by applying a filter paper moistened with a solution containing $5 \mathrm{~g} / \mathrm{I} \mathrm{NaCl}$ and $10 \mathrm{~g} /$ / potassium hexacyanoferrite (III).

The resistance of nickel-containing coatings to abrasion was investigated on a modernized Taber Elcometer 5135 rotary abrasimeter. Flat samples with coatings were attached to the mounting levers and pressed against the felt disk with the same external load on both levers equal to $3.5 \mathrm{~N} / \mathrm{cm}^{2}$. The abrasion of the samples was carried out with the rotation of the felt disk with a rotation speed of $60 \mathrm{rpm}$. Resistance to abrasion of the samples was evaluated by the number of cycles until the first signs of abrasion. One cycle was one full circle of a felt disc.

The thickness of the forming coating was determined using the "Constant K6G" (Russia) electroplating multifunctional thickness meter.

Corrosion tests of samples with nickel coating were carried out in a salt fog chamber Ascott S450iP (UK) for 1 day in accordance with international standard ASTM B117.

The composition of the black nickel-containing coating was investigated by X-ray fluorescence spectrometry using an EDX-7000 energy dispersive spectrometer (Shimadzu, Japan).

The XPS spectra were recorded using a special CLAM100 camera mounted on an Auger microscope HB100 (Vacuum Generators, GB). The pressure in the working chamber was maintained below 10-8 Torr. The Alanode $(1486.6 \mathrm{eV})$ with a power of $200 \mathrm{~W}$ was used as an X-ray source. The instrument was calibrated by XPS of $\mathrm{Au} 4 \mathrm{f} 7 / 2$ metal peaks $(E b=84.0 \mathrm{eV}), \mathrm{Cu} 2 \mathrm{p} 3 / 2(\mathrm{~Eb}=932.5 \mathrm{eV})$. The pass energy of analyzer was set at $50 \mathrm{eV}$.

According to the results of the study were obtained survey spectra of coatings, which were decomposed into the constituent spectra of the elements after subtracting the background.

The study of the morphology and surface roughness of coated samples was carried out using an MPLAPONLEXT 100 lens on a LEXT - OSL 4100 (Japan) confocal laser microscope. To assess the structure of the layer, as well as the degree of surface development, images of the surface of the same sample were obtained at different stages of surface preparation and after the formation of a conversion coating. The measurements were carried out in two-dimensional and three-dimensional coordinate systems.

\section{EXPERIMENTAL WORK}

The object of the study was a solution containing, $\mathrm{g} / \mathrm{l}$ : $\mathrm{NiSO}_{4} \cdot 7 \mathrm{H}_{2} \mathrm{O}-100 ;\left(\mathrm{NH}_{4}\right)_{2} \mathrm{SO}_{4}-15$; $\mathrm{ZnSO}_{4} \cdot 7 \mathrm{H}_{2} \mathrm{O}-40 ; \mathrm{NH}_{4} \mathrm{CNS}-15$; $\mathrm{H}_{3} \mathrm{BO}_{3}$ - 25. The electrolyte temperature is $50^{\circ} \mathrm{C}, \mathrm{pH}=4.5-5.5$ [2].

\section{Process Parameter Definition}

In order to determine the optimal concentration in the electrolyte of zinc sulfate and ammonium rhodanide, their effect on the appearance of the coatings was studied depending on the cathode current density. As can be seen from Figure 1, high-quality black

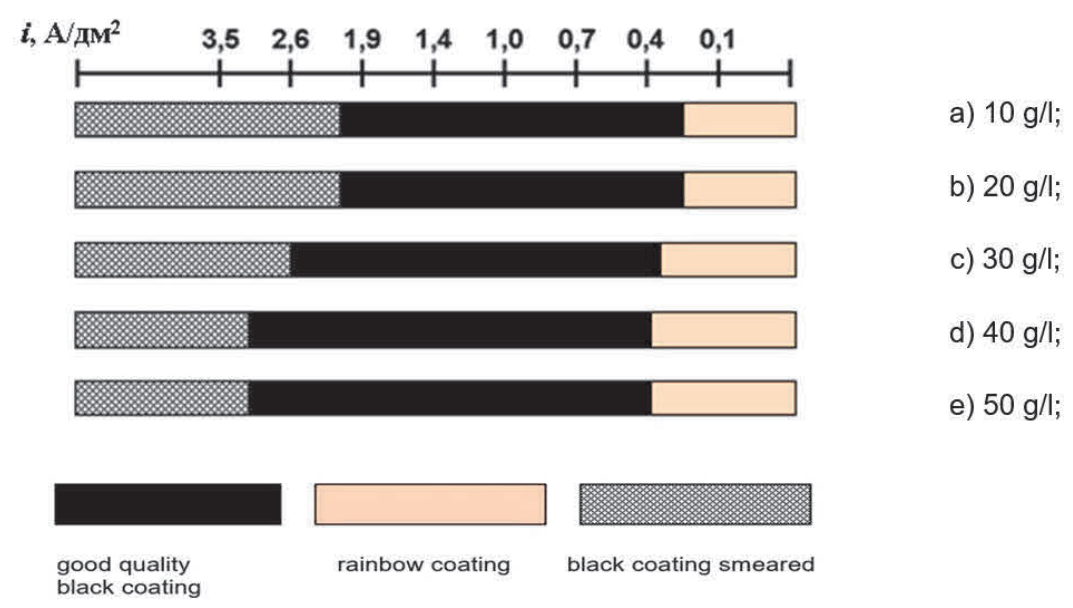

Figure 1 Dependence of the quality of the coating on the concentration of ZnSO4 and cathode current density: a) $10 \mathrm{~g} / \mathrm{l}$; b) $20 \mathrm{~g} / \mathrm{l}$; c) $30 \mathrm{~g} / \mathrm{l}$; d) $40 \mathrm{~g} / \mathrm{l}$; e) $50 \mathrm{~g} / \mathrm{l}$ 
coating is deposited in the widest range of current densities when the concentration of zinc sulfate in the electrolyte is $30-50 \mathrm{~g} / \mathrm{I}$. It was established experimentally that a decrease in temperature (below $40{ }^{\circ} \mathrm{C}$ ) is undesirable, since it leads to deterioration in the quality of coatings - they become gray and smear.

Solution composition: $\mathrm{NiSO}_{4}-100 \mathrm{~g} / \mathrm{I},(\mathrm{NH}){ }_{4} \mathrm{SO}_{4}-15 \mathrm{~g} / \mathrm{l}, \mathrm{NH}_{4} \mathrm{CNS}-15 \mathrm{~g} / \mathrm{l}, \mathrm{H}_{3} \mathrm{BO}_{3}-25 \mathrm{~g} / \mathrm{l}$, temperature $50^{\circ} \mathrm{C}, \mathrm{pH}=4.5-5.5$

As can be seen from the data in Figure 2, black coatings of good quality in the widest range of current densities are deposited when the content in the solution is $15 \mathrm{~g} / \mathrm{l}$ of ammonium rhodanide.
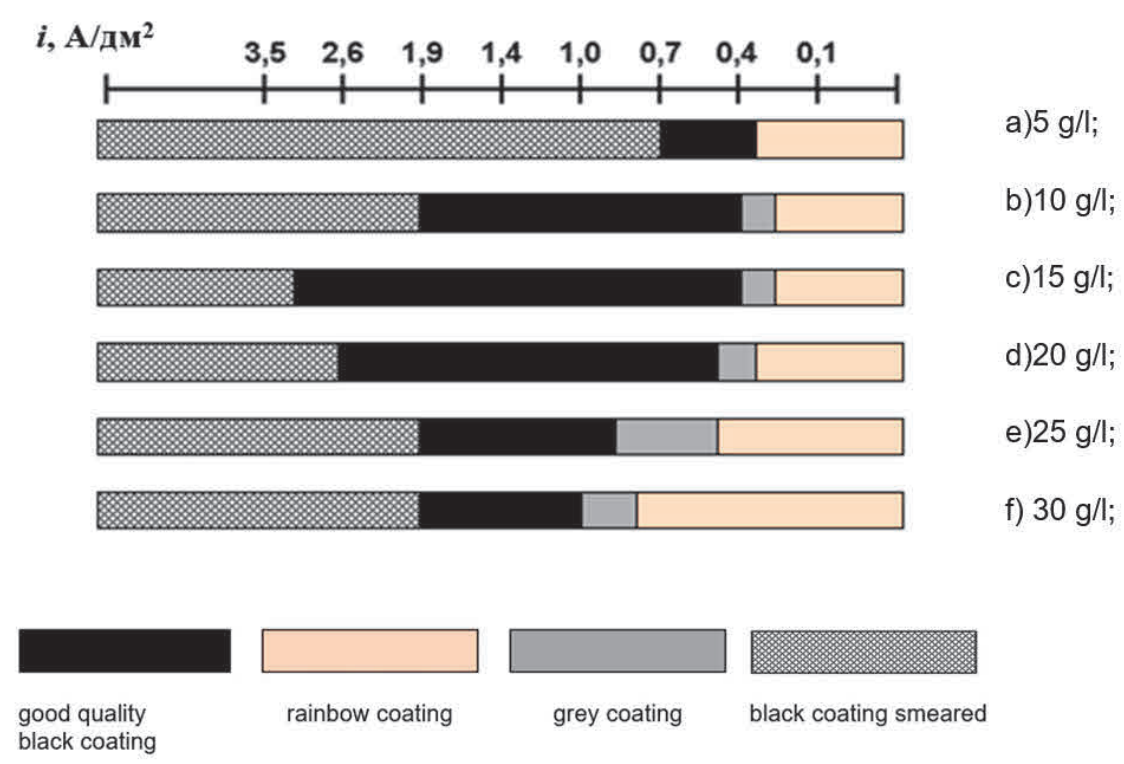

Figure 2 Dependence of the quality of the coating on the concentration of $\mathrm{NH}_{4} \mathrm{CNS}$ and cathode current density: a) $5 \mathrm{~g} /$ / ; b) $10 \mathrm{~g} /$ /; c) $15 \mathrm{~g} /$ l; d) $20 \mathrm{~g} /$ l; e) $25 \mathrm{~g} / \mathrm{l}$; f) $30 \mathrm{~g} / \mathrm{l}$

The composition of the solution: $\mathrm{NiSO}_{4}-100 \mathrm{~g} / \mathrm{l},(\mathrm{NH}){ }_{4} \mathrm{SO}_{4}-15 \mathrm{~g} / \mathrm{l}, \mathrm{ZnSO}_{4}-40 \mathrm{~g} / \mathrm{l}, \mathrm{H}_{3} \mathrm{BO}_{3}-25 \mathrm{~g} / \mathrm{l}$, temperature $50^{\circ} \mathrm{C}, \mathrm{pH}=4.5-5.5$.

It was revealed that the $\mathrm{pH}$ range of $4.5-5.5$ is optimal for the deposition of high-quality black coatings. At a $\mathrm{pH}$ of more than 5.5, no coating is formed, and a white loose sediment falls out in the electrolyte. At a pH of less than 4.5, friable coatings that are not uniform in color are formed. Studies of the protective ability and wear resistance of coatings deposited under the above conditions showed that they are inferior to black chrome coatings in terms of corrosion resistance and abrasion resistance (Table 1).

Table 1 Abrasion resistance and protective ability of black coatings

\begin{tabular}{|l|c|c|}
\hline \multirow{2}{*}{ Test result } & \multicolumn{2}{c|}{ Coating } \\
\cline { 2 - 3 } & $\mathbf{N i}$ & $\mathbf{C r}$ \\
\hline Resistance to abrasion, the number of cycles to complete abrasion of coating & 3000 & 13000 \\
\hline The time until the first products of corrosion base, $\mathrm{h}$ & 50 & 120 \\
\hline
\end{tabular}

The possibility of improving these characteristics by changing the current mode during the deposition process was investigated. In particular, the possibility of deposition of black nickel-containing coatings using stepwise mode of current change was investigated [8]. This method of coating formation is based on the deposition of the first layer of bright nickel and the subsequent layer of "black" in the same electrolyte at different current densities. It is assumed that in the first stage (at relatively low current densities), bright nickel is deposited, providing adhesion to the substrate, and a black coating is deposited on this layer at higher current densities. 
It is established that the porosity of the coating deposited in the stepwise mode of current change is less than the porosity of the coatings obtained at constant current density $\left(1 \mathrm{pc} / \mathrm{cm}^{2}\right.$ versus $\left.3 \mathrm{pcs} / \mathrm{cm}^{2}\right)$. It should be noted that in this case the thicknesses indicated are equal to $1 \mu \mathrm{m}$ and $2 \mu \mathrm{m}$, respectively. It has been established when due to a change in the current mode during the deposition process, thinner, but less porous, durable coatings are formed. In addition, it was found that in this case, in the presence of a nickel sublayer with a thickness of $10 \mu \mathrm{m}$, precipitated from the Watt's plating solution, the total coating with a black layer becomes completely nonporous.

\section{CHARACTERIZATION AND FUNCTIONAL TESTS OF COATINGS}

It was found that the abrasion resistance of black nickelcontaining coatings deposited in a stepwise mode is much higher than the abrasion resistance of black chrome coatings, as well as black nickel-containing coatings applied at a constant current density: the number of cycles to abrasion is $24,000,13,000$, and 3000 cycles and the protective ability is 160,120 and 90 hours respectively.

In the present work, the composition of the deposited coatings was studied using X-ray fluorescence spectrometry. It was established that black nickel coatings deposited at constant current density contain mainly nickel (58\%), zinc (30\%) and sulfur (12\%). When precipitating nickel in a stepwise mode, the coating mainly consists of zinc (59\%), nickel $(28 \%)$ and sulfur (13\%).

From the data presented in Figure 3, it can be seen that at low current densities (of the order of 0.02-0.04 A / dm²), nickel mainly precipitates into the coating (46\%), and the zinc content is much lower $(20 \%)$. It was stated that after a current jump, the amount of zinc in the coating increases

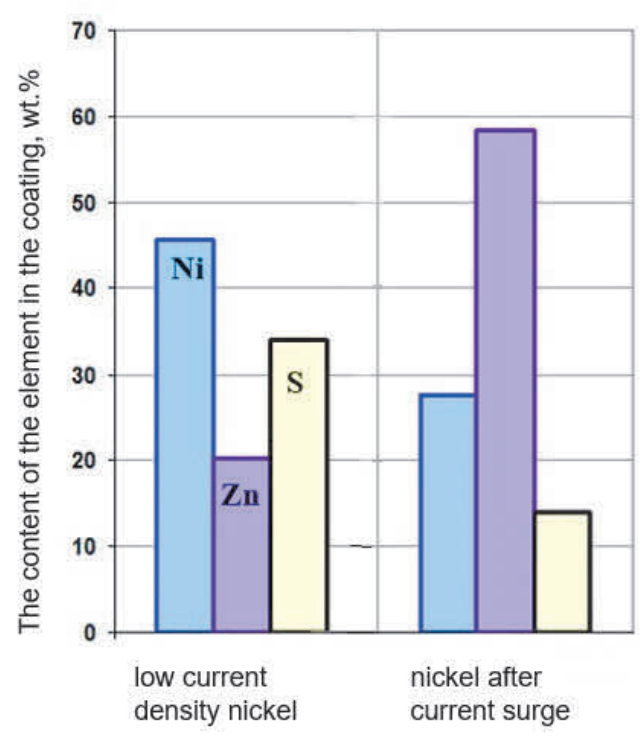

Figure 3 Content of elements in the coating, depending on the current density dramatically up to $59 \%$.

Apparently, the cause of the observed effects is a change in the deposition potential. It is known that the standard $\mathrm{Ni}$ (II) reduction potential is about $0.5 \mathrm{~V}$ more positive than the $\mathrm{Zn}$ reduction potential from $\mathrm{Zn}$ (II). Therefore, at lower current densities and, consequently, lower potentials, nickel will predominantly be deposited, and at higher currents (and, consequently, potentials), predominant deposition of zinc should be observed [8]. This is confirmed by the results obtained by electrodeposition of nickel at a constant high current density. The coating obtained at a constant current density of $1.5 \mathrm{~A} / \mathrm{dm}^{2}$ contains $24 \% \mathrm{Ni}, 65 \% \mathrm{Zn}$ and $11 \%$ $\mathrm{S}$. It should be noted that this results in formation of dark gray coatings, but not the black ones, as in the stepwise deposition.

By means of X-ray photoelectron spectroscopy, it was possible to establish the chemical composition of the coatings. It was stated that the coating mainly consists of metallic nickel, as well as nickel and zinc sulfides.

It is established that the black coating obtained in one stage at a constant current density of $0.5 \mathrm{~A} / \mathrm{dm} 2$ has a roughness of $\mathrm{Ra}=0.262 \mu \mathrm{m}$.

As for the stepwise deposited coatings, first, at low current densities (0.02-0.04 A / dm²), coatings with a roughness of $R a=0.053 \mu \mathrm{m}$ are deposited. With an increase in current density to $0.2 \mathrm{~A} / \mathrm{dm}^{2}$, there is a slight increase in roughness to $\mathrm{Ra}=0.086 \mu \mathrm{m}$, and then, after a sudden increase in current density to $1.5 \mathrm{~A} / \mathrm{dm}^{2}$, the roughness of the deposited black coating increases 26 times and is $2.233 \mu \mathrm{m}$ (Figure 4). 
At high values of $\mathrm{Ra}$ of the surface, its light absorption begins to dominate over reflection, and the specular reflection is completely replaced by diffuse scattering. Due to such optical phenomena, the coating is perceived as a matte black coating.

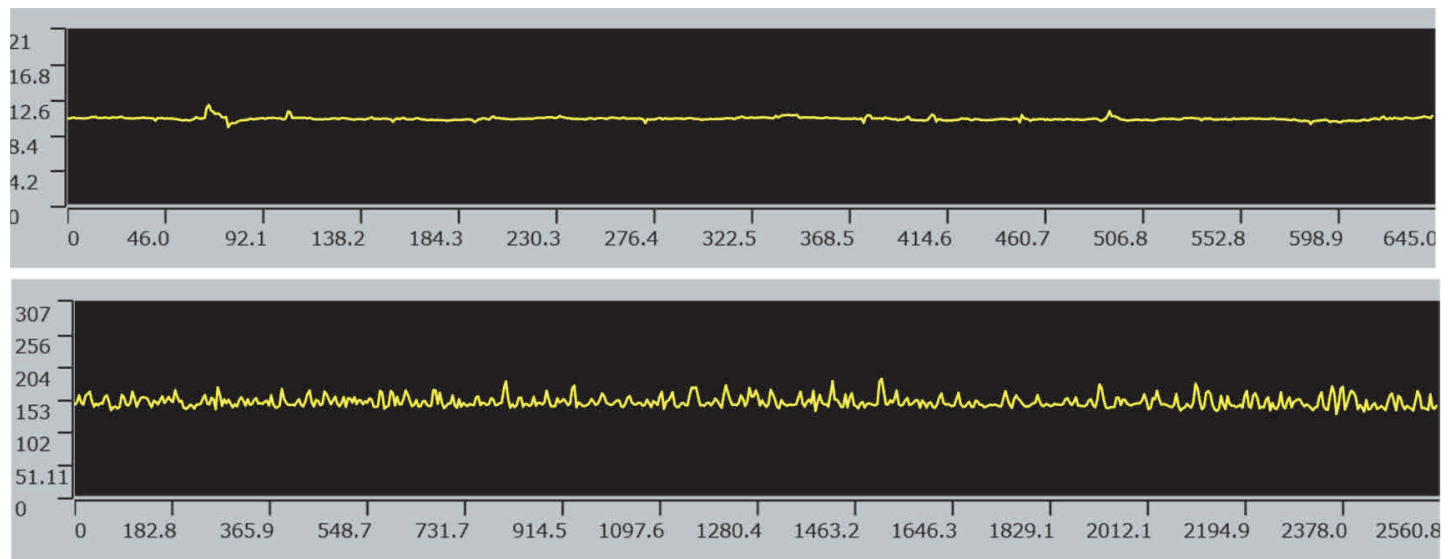

Figure 4 Profilograms of the surface of the steel sample before (a) and after (b) coating deposition. It should be noted that the coating obtained at a constant current density of $0.5 \mathrm{~A} / \mathrm{dm}^{2}$ has a roughness of

$$
\mathrm{Ra}=0.262 \mu \mathrm{m}
$$

\section{CONCLUSION}

The possibility of obtaining black nickel-containing coatings is shown; the influence of various factors on the characteristics of coatings is established.

The chemical composition of the coating and its dependence on the process parameters, as well as protective ability, corrosion resistance and abrasion resistance of black coatings were studied. A method of deposition of black nickel-containing coatings at stepwise change of the cathode current density from low values at gradual increase of the current density every minute by $0.1 \mathrm{~A} / \mathrm{dm}^{2}$ during 10 minutes, then the current density increases 7.5 times and maintained during 5 minutes.

\section{ACKNOWLEDGEMENTS}

"The work was supported by the Mendeleev University of Chemical Technology of Russia. Project Number 016-2018”.

\section{REFERENCES}

[1] RUDENKO M.F., KRAVTSOV E.E. and IDIATULIN S.A. Effective surfaces of solar cells // Chemical and oil and gas engineering. 1998. no. 7, pp. 33-35.

[2] TAKADOUM J. Black coatings: a review // The European physical journal applied physics. 2010. vol. 52, no. 3, pp. 1-7.

[3] KARUPPIAH N., JOHN S., NATARAJAN S. and SIVAN V. Characterization of electrodeposited Nickel-Cobalt selective black coatings - scanning electron microscopic studies // Bulletin of Electrochemistry. 2002. no. 18(7), pp. 295-298.

[4] ARAVINDA C.L., BERA P., JAYARAM V., SHARMA A.K., et. al. Characterization of electrochemically deposited Cu-Ni black coatings // Materials research bulletin. 2002. vol.37, no 3, pp. 397-405.

[5] SHAWKI S. and MIKHAIL S., Black Nickel Coatings for Solar Collectors // Materials and Manufacturing Processes. 2000. vol.15, no. 5, pp. 737-746.

[6] SIDELNIKOVA S.P., YUSHCHENKO S.P. and DIKUSAR A.I. Morphology, Structure and Composition of Coatings during Electrodeposition of Black Nickel // Electronic Processing of Materials. 2009. no 45(4). pp. 334-341. 